\title{
Functional trait differences between native bunchgrasses and the invasive grass Bromus tectorum
}

\author{
Huiqin HE ${ }^{1}$, Thomas A. MONACO $(\bowtie)^{2}$, Thomas A. JONES ${ }^{2}$ \\ 1 College of Resources and Environmental Engineering, Yibin University, Yibin 644000, China \\ 2 U.S. Department of Agriculture, Agricultural Research Service, Forage and Range Research Laboratory, Utah State University, \\ Logan, UT 84322-6300, USA
}

\begin{abstract}
We conducted 30- and 60-d greenhouse experiments to compare functional traits of Bromus tectorum (invasive annual grass) and four perennial bunchgrasses under well-watered or drought conditions. Even under drought, B. tectorum experienced significantly less stress (i.e., higher xylem pressure potential and greater shoot water content, water use per day and water-use efficiency) and biomass production than the perennial grasses after $30 \mathrm{~d}$. However, after $60 \mathrm{~d}$, its superiority was reduced under infrequent watering. Differences among perennial grasses were more pronounced for physiological traits under infrequent watering and for morphological traits under frequent watering. Elymus multisetus (fastgrowing species) had a higher transpiration rate, lower leaf temperature, and lower water-use efficiency than the other grasses after $30 \mathrm{~d}$. In contrast, Pseudoroegneria spicata (slow-growing) had lower xylem pressure potential and higher leaf temperature than all other grasses under infrequent watering. Under frequent watering, shoot dry mass and specific leaf area of $B$. tectorum was matched by Elymus wawawaiensis (moderate-growing species). Our results indicate that multiple-species plantings or seedings are necessary to foster greater weed resistance against $B$. tectorum. We also emphasize that when choosing plant material for restoration, performance during both pulse (resource-rich) and inter-pulse (resource-poor) periods should be considered.
\end{abstract}

Keywords annual grass, comparative growth, drought response, invasive plant, native grass, specific leaf area, soil-water use

\section{Introduction}

Native perennial bunchgrasses have long been recognized as an integral functional component of shrub-steppe ecosystems of western North America ${ }^{[1]}$. Dominance of these perennial grasses has steadily declined since European settlement due to inadequate grazing tolerance and widespread invasion by annual grass species, foremost among them Bromus tectorum ${ }^{[2,3]}$. Land managers quickly realized that native perennial grasses would not persist under heavy grazing, frequent wildfire regimes and intense $B$. tectorum competition ${ }^{[4,5]}$. While introduced forage grasses have historically been used to stabilize soils and support livestock grazing ${ }^{[6,7]}$, rehabilitation success has been considerably less with the reintroduction of native perennial grasses ${ }^{[8]}$.

Evidence indicates that the invasive annual grass, $B$. tectorum, is superior to native perennial grasses for shoot and root production, nitrogen utilization and water extraction when soil resources are abundant ${ }^{[9-11]}$. However, it remains unclear whether these advantages over perennial grasses are conserved when seedlings are exposed to drought conditions. For example, Mukherjee et al. ${ }^{[12]}$ found that considerable variation exists between native populations of perennial grasses in response to drought and that certain populations may be better competitors with $B$. tectorum $^{[13,14]}$. To clarify key functional differences between native grass species and $B$. tectorum, it is critical to compare morphological and physiological traits under conditions when resources are abundant and when they are limiting ${ }^{[15]}$.

Wild populations and improved cultivars of native grasses accommodate the growing demand for native species in ecosystem restoration ${ }^{[16]}$. Many native perennial grasses are available for shrub-steppe ecosystems of western North America, including fast-growing squirreltail (Elymus multisetus), moderate-growing Snake River wheatgrass (Elymus wawawaiensis) and slow-growing

Received August 2, 2017; accepted October 12, 2017

Correspondence: tom.monaco@ars.usda.gov

(C) The Author(s) 2017. Published by Higher Education Press. This is an open access article under the CC BY license (http://creativecommons.org/licenses/by/4.0) 
bluebunch wheatgrass (Pseudoroegneria spicata). However, comprehensive comparisons with B. tectorum, especially in response to drought stress, are needed to make sound decisions regarding their suitability for restoration. Consequently, in this study, our objective was to compare 10 functional traits of $B$. tectorum and these important perennial grasses under well-watered and drought conditions to (1) determine how drought differentially affects seedling functional traits and (2) elucidate how trait differences among perennial grasses can be used to improve seedling establishment success and competition with $B$. tectorum. Ultimately, these new insights may facilitate trait-based selection of perennial grasses for grassland and shrub-steppe restoration projects.

\section{Materials and methods}

Seed of B. tectorum was collected from a south-westfacing slope at $1450 \mathrm{~m}$ elevation in the north-eastern portion of the Great Basin, USA $\left(41^{\circ} 46^{\prime} 07^{\prime \prime} \mathrm{N}, 111^{\circ} 47^{\prime} 11^{\prime \prime}\right.$ W). Seed of E. multisetus selection Sand Hollow, E. wawawaiensis cv. Secar and selection E-45, and Pseudoroegneria spicata. Goldar was obtained from the seed repository at the US Department of Agriculture, Agricultural Research Service, Forage and Range Research Laboratory in Logan, UT, USA. All seed had been stored at $4^{\circ} \mathrm{C}$ prior to these studies. E- 45 had undergone two cycles of recurrent selection for general population improvement from cv. Discovery, a multipleorigin material from Whitman and Asotin Counties (WA, USA) and Idaho County (ID, USA).

Seed was germinated on moistened blotting paper in Petri dishes. Experimental units consisted of a germinated seedling transplanted into a $0.5-\mathrm{L}$ plastic container filled with $525 \mathrm{~g}$ of Preston fine sand (mixed, mesic, Typic Xeropsamments) collected in Cache County (UT, USA). To compensate for different seedling growth rates, B. tectorum seeds were imbibed $7 \mathrm{~d}$ later than the perennial grasses, so seedlings would be of similar size at transplanting. Two independent randomized complete block experiments were established in a greenhouse at Utah State University, Logan. Experiments were located on different benches in the same greenhouse, and initiated on the same day in September. Both consisted of 14 blocks with randomly arranged combinations of the five grasses and two watering-frequency treatments, and they were terminated after 30 and $60 \mathrm{~d}$, respectively. Mean hourly greenhouse net radiation during the 60 days peaked at hour 15:00, while air temperature and relative humidity remained relatively stable at $20^{\circ} \mathrm{C}$ and $35 \%$, respectively.

Containers received $40 \mathrm{~mL}$ of water-soluble nutrient solution (24-8-16 NPK with micronutrients; Scotts Miracle-Gro Products Inc., Marysville, OH, USA) and were watered every other day to maintain field capacity, i.e., $11.5 \%$ soil-water content, for three weeks prior to applying water treatments. Soil-water content was determined gravimetrically by weighing the containers on an electronic microbalance. We created watering-frequency treatments to evaluate functional traits under low (drought) and high resource availability ${ }^{[17]}$. Containers were either watered to field capacity every $2 \mathrm{~d}$ (frequent watering) or $4 \mathrm{~d}$ (infrequent watering). Extensive preliminary experiments were conducted with variable watering regimes to ensure frequent watering maintained soil-water content (SWC) between $8 \%$ and $11.5 \%$ and infrequent watering stressed plants by allowing SWC to drop to $4 \%$ before recharging to $11.5 \%$ without causing seedling mortality.

At the end of each experiment (i.e., 30 or $60 \mathrm{~d}$ ), all plants were watered to field capacity in the early morning and physiological and morphological traits measured, one block at a time by randomly selecting plants. Transpiration rate and leaf temperature were measured for one leaf per seedling under ambient temperature and light conditions using a calibrated steady-state porometer (LI-1600, Li-Cor Corp., Lincoln, NE, USA.) affixed with a small aperture $\left(0.60 \mathrm{~cm}^{2}\right)$ between hour 11:00 and 13:00. Measurements were made on recently expanded leaves of similar size and hierarchical generation (third) from the seminal tiller. Leaves were immediately excised with a sharp razor, placed between a slit in a rubber gasket, and mounted in a Scholander-type pressure chamber (Model 1000, PMS Instrument Co., Corvallis, OR, USA.) to determine leaf water potential (xylem pressure potential) using standard procedures ${ }^{[18]}$. Shoots, including the subterranean crown portion and excised leaves, were then harvested and immediately weighed, dissected, and measured with a beltdriven leaf-area meter (LI-3000/3050A, Li-Cor Corp.). Root systems were gently rinsed with water to remove soil. Shoots and roots were dried in a convective oven at $60^{\circ} \mathrm{C}$ for $48 \mathrm{~h}$ and weighed to determine shoot and root dry mass. Shoot water content and specific leaf area (SLA) were calculated from the difference between fresh and dry shoot mass and the quotient of leaf area and shoot dry mass, respectively.

Given that each container was weighed and watered to maintain $11.5 \%$ soil-water content every two or four days, we were able to calculate water use per day (quotient of total water provided and days of experiment, i.e., 30 or $60 \mathrm{~d}$ ) and shoot growth water-use efficiency (quotient of shoot dry mass and total water provided). When calculating water-use traits, we could not account for variation in container mass attributed to plant dry mass and/or plantwater mass; however, this variation was considered of minor significance because the greatest shoot fresh mass value determined after the 60 -d experiment was only $4 \mathrm{~g}$, an amount that corresponds to only $0.64 \%$ of total container mass at $11.5 \%$ soil-water content $(624 \mathrm{~g})$. Water loss from containers without plants was negligible.

All growth and water-use traits were analyzed with mixed-effect ANOVA models using JMP (ver. 11, SAS Institute Inc., Cary, NC, USA). Entries and treatment were 
considered fixed effects and replicate (block) was considered a random effect. Means were compared with Fisher's Protected LSD test. Tests of significance for mainand interaction-effects are shown in figures, and significance for mean-separation tests was determined at $\alpha=$ 0.05 .

\section{Results}

The main-effect of watering frequency significantly impacted all functional traits in the two experiments, with the exception of root dry mass at $30 \mathrm{~d}$ and water-use efficiency at $60 \mathrm{~d}(P<0.05)$. Watering frequency rarely had the same effect on the five grasses. Instead, we found a significant interaction between watering frequency and grasses $(P<0.05)$ for all 10 traits in at least one of the experiments ( 30 or $60 \mathrm{~d})$. Results indicate that the grasses differentially responded to drought conditions and reveal key traits that must be considered in order to improve seedling establishment of perennial grasses and increase their ability to compete with $B$. tectorum.

Xylem pressure potential and shoot water content were highest for $B$. tectorum and lowest for the slow-growing $P$. spicata under infrequent watering at $30 \mathrm{~d}$ (Fig. 1). In addition, $P$. spicata showed relatively greater reductions in

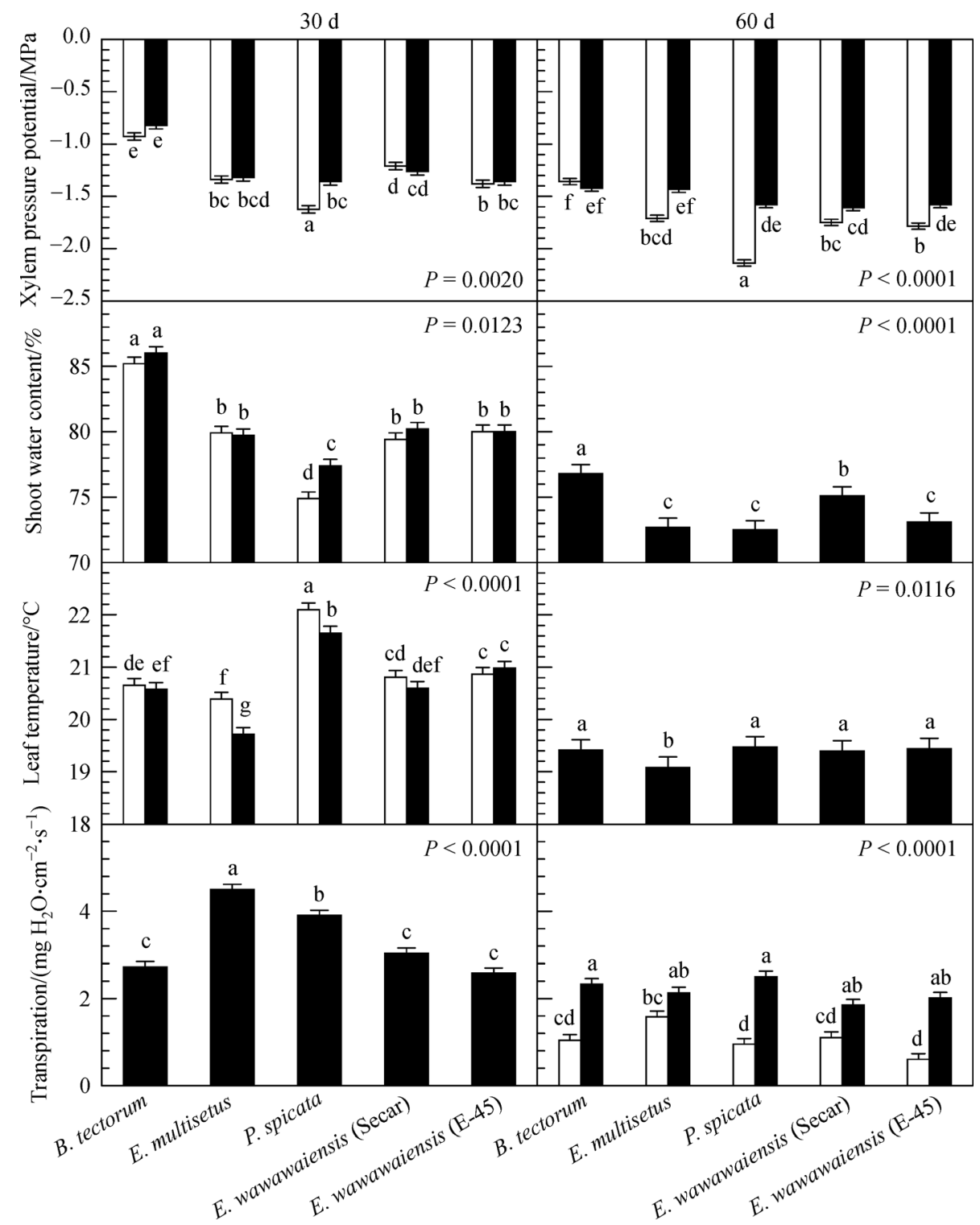

Fig. 1 Mean ( + $1 \mathrm{SE}$ ) xylem pressure potential, shoot water content, leaf temperature and transpiration rate of five grasses (Bromus tectorum, Elymus multisetus, Pseudoegneria spicata, Elymus wawawaiensis cv. Secar and Elymus wawawaiensis selection E-45) grown with infrequent (open bars) and frequent watering (closed bars) in 30- and 60-d greenhouse experiments. Means for entries $(n=28)$ or entry by treatment $(n=14)$ with the same lowercase letter are not significantly different $(P>0.05)$. ANOVA significance for entry maineffect or entry by treatment interaction is indicated. 
xylem pressure potential than the other perennial grasses under infrequent watering at both 30 and $60 \mathrm{~d}$. Leaf temperatures were consistently lowest for fast-growing $E$. multisetus and greatest for $P$. spicata at $30 \mathrm{~d}$, and were greater under infrequent than frequent watering for both species. Transpiration rates of E. multisetus and P. spicata were also greater than the other grasses at $30 \mathrm{~d}$. However, at $60 \mathrm{~d}$, transpiration rate of E. multisetus was greater than that of only two perennial grasses under infrequent watering (i.e., P. spicata and E. wawawaiensis E-45).

Shoot and root dry masses, leaf areas, and specific leaf areas were consistently greater for $B$. tectorum than for the bunchgrasses at $30 \mathrm{~d}$ (Fig. 2). However, at $60 \mathrm{~d}, B$. tectorum was matched under infrequent watering by at least one of the E. wawawaiensis populations for shoot dry mass and specific leaf area, and by all grasses except $P$. spicata for root dry mass. Specific leaf area of both $E$. wawawaiensis entries exceeded the other perennial grasses at $30 \mathrm{~d}$, and values matched $B$. tectorum under frequent watering at $60 \mathrm{~d}$. Likewise, root dry mass of both $E$. wawawaiensis entries exceeded the other perennial grasses at $60 \mathrm{~d}$ and showed marked increases under frequent watering (e.g., similar to B. tectorum).

Water use and water-use efficiency of B. tectorum were

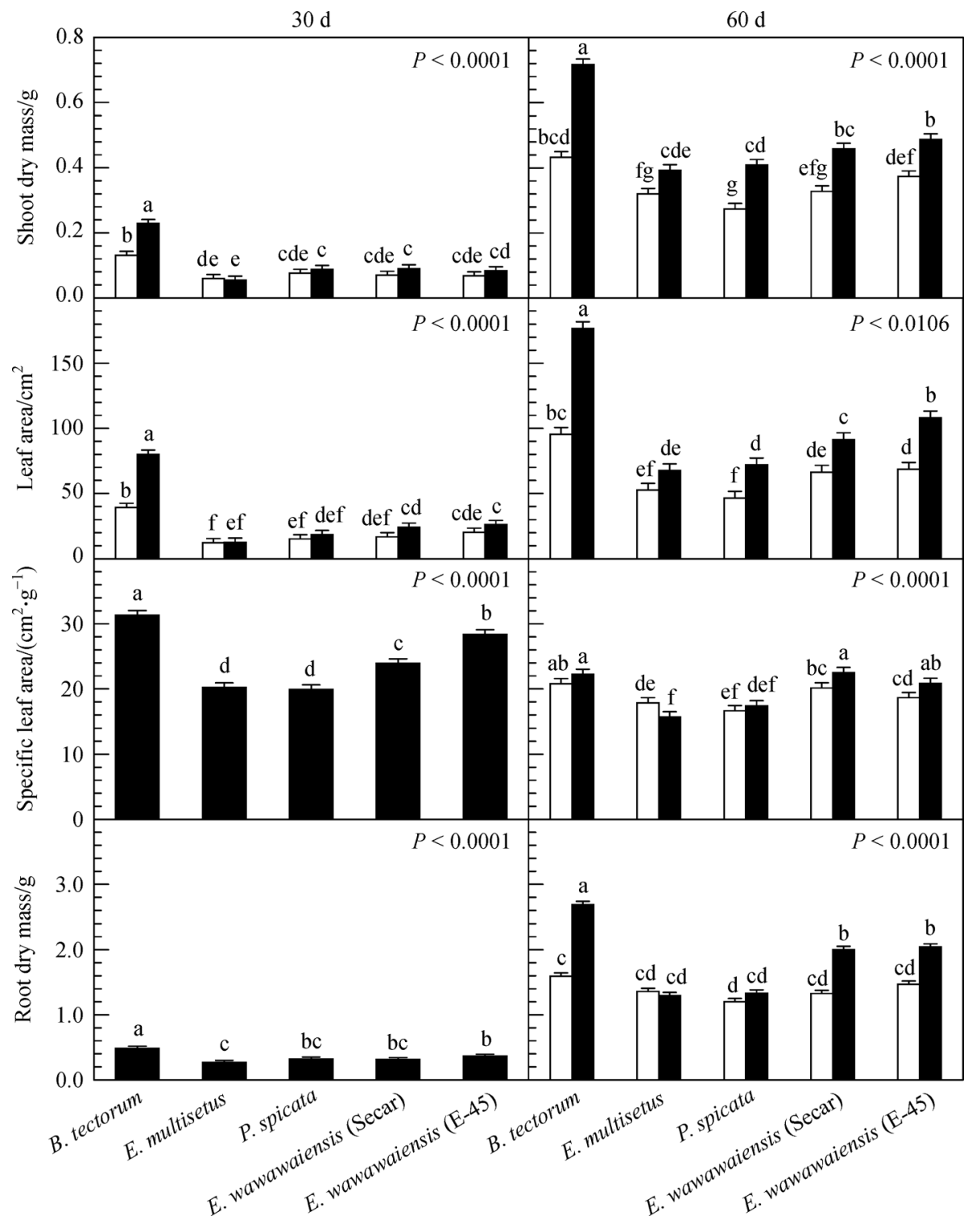

Fig. 2 Mean ( $+1 \mathrm{SE})$ shoot dry mass, leaf area, specific leaf area, and root dry mass of five grasses (Bromus tectorum, Elymus multisetus, Pseudoegneria spicata, Elymus wawawaiensis cv. Secar and Elymus wawawaiensis selection E-45) grown with infrequent (open bars) and frequent watering (closed bars) in 30- and 60-d greenhouse experiments. Means for entries $(n=28)$ or entry by treatment $(n=14)$ with the same lowercase letter are not significantly different $(P>0.05)$. ANOVA significance for entry main-effect or entry by treatment interaction is indicated. 


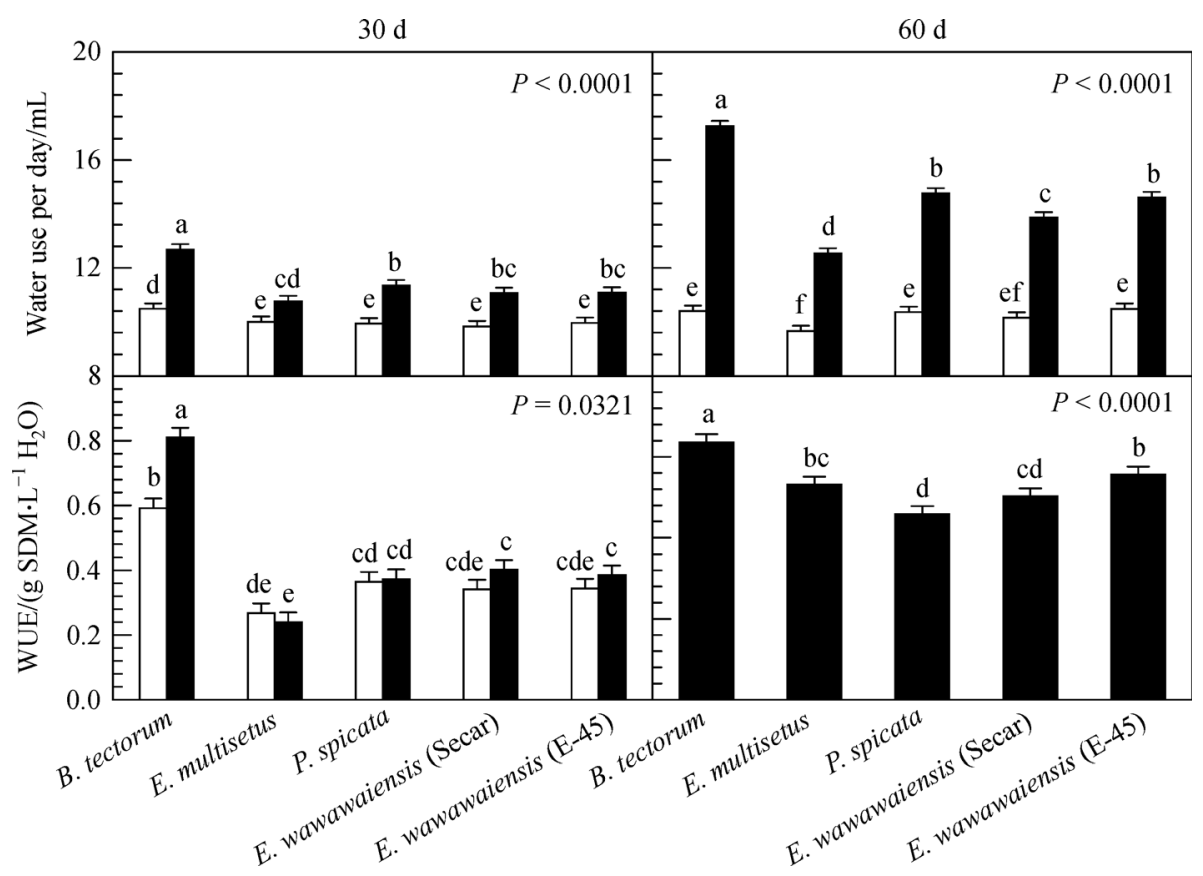

Fig. 3 Mean ( $+1 \mathrm{SE}$ ) water use per day and shoot growth water-use efficiency (WUE) of five grasses (Bromus tectorum, Elymus multisetus, Pseudoegneria spicata, Elymus wawawaiensis cv. Secar and Elymus wawawaiensis selection E-45) grown with infrequent (open bars) and frequent watering (closed bars) in 30- and 60-d greenhouse experiments. Means for entries $(n=28)$ or entry by treatment $(n=14)$ with the same lowercase letter are not significantly different $(P>0.05)$. ANOVA significance for entry main-effect or entry by treatment interaction is indicated

significantly greater than the perennial grasses at $30 \mathrm{~d}$ (Fig. 3). Elymus multisetus also showed less divergence between watering treatments and had lower water use than the other perennial grasses under frequent watering at $60 \mathrm{~d}$. Only B. tectorum had greater water-use efficiency under frequent compared to infrequent watering. Water-use efficiency was lowest for E. multisetus and P. spicata at 30 and $60 \mathrm{~d}$, respectively.

\section{Discussion}

Interpreting differential drought responses of perennial grasses is challenging because plant effects on soil-water availability are difficult to distinguish from plant responses to soil-water availability ${ }^{[19]}$. Furthermore, differential water use is ecologically important because it provides additional awareness of how a species may directly influence its own growth and indirectly affect growth of neighboring species in field settings. Our results clearly indicate that physiological and morphological traits were consistently hindered by low watering frequency, yet reductions were differentially expressed among species. These drought responses provide new insights into functional-trait differences between perennial grasses and identify a number of traits that may limit successful seedling establishment and competition with B. tectorum.

\subsection{Differential physiological traits}

Low soil-water availability arguably poses one of the greatest threats to the survival of perennial grass seedlings ${ }^{[20]}$. During this sensitive developmental stage, seedlings must exhibit physiological traits to successfully persist under the biotic, atmospheric and edaphic stresses associated with variable and/or diminishing soil-water content ${ }^{[21]}$. Our results indicate that slow-growing $P$. spicata has lower capacity to avoid drought stress relative to the other perennial grasses based on it exhibiting lower xylem pressure potential, low shoot water content, and elevated leaf temperature at this critical seedling stage, i.e., $30 \mathrm{~d}$.

Given that leaf area and root biomass of bunchgrasses were relatively similar during early developmental stages (i.e., $30 \mathrm{~d}$ ), lower xylem pressure potential and lower shoot water content of $P$. spicata were likely driven by its higher transpiration rates ${ }^{[17]}$. In addition, high leaf temperature of $P$. spicata was possibly an indirect consequence of the lack of leaf pubescence in this species ${ }^{[22]}$. Leaf pubescence is a distinguishing trait present on seedlings of the other perennial grasses ${ }^{[23]}$ and is known to reduce absorbance, heat loading and transpiration rates in semiarid plants ${ }^{[24]}$. However, high transpiration rates at midday had lessnegative impacts on leaf water status of E. multisetus. High transpiration and its contribution to latent heat exchange $\mathrm{e}^{[25]}$ may be a drought-avoidance mechanism by which 
E. multisetus experiences lower leaf temperature than the other perennial grasses, even when they have more favorable (i.e., less negative) leaf xylem pressure potentials.

Our results offer two insights into competition with $B$. tectorum and relative establishment potential of perennial grasses. First, previous research suggests that high growth rate, short lifespan and vigorous root growth of E. multisetus ${ }^{[26-28]}$ enable it to successfully compete with annual grasses ${ }^{[5,29]}$. Our results indicate that its ability to compete with annual grasses may also be associated with high rates of transpiration to maintain low leaf temperature during young seedling growth (i.e., $30 \mathrm{~d}$ ); traits necessary to exhaust soil resources before they can be acquired by annual grasses. Indeed, field experiments similarly illustrate that successful competitors must rapidly deplete early spring and localized soil water, while avoiding drought stress associated with coexistence with annual grasses ${ }^{[30]}$. Second, differential physiological and water-use patterns among perennial grasses help explain previous observations of lower summer survival of P. spicata cv. Goldar than E. wawawaiensis cv. Secar when drought conditions persist ${ }^{[12,31]}$. For example, under infrequent watering, our observation of lower leaf water stress, higher shoot water content, lower leaf temperature and lower leaf transpiration in young seedlings of E. wawawaiensis cv. Secar (i.e., 30 d) indicate a clear drought-avoidance advantage relative to P. spicata cv. Goldar during the critical establishment phase. Although the strategies employed by the perennial grasses to cope with drought conditions were very different, additional research is needed to explore potential trade-offs encountered when species exhibit higher resource acquisition (i.e., E. multisetus) vs higher drought avoidance (i.e., E. wawawaiensis).

\subsection{Differential morphological traits}

Synchronizing morphological traits of perennial grasses with $B$. tectorum when soil resources are abundant may also enhance establishment of restoration species. While, this approach is common in crop breeding to improve the competitive ability of crops when competing with undesirable weeds ${ }^{[32]}$, it has received less emphasis for native perennial grasses ${ }^{[33,34]}$. As a result of the necessary trade-offs, however, the traits that confer competitiveness may be entirely different than the traits that confer physiological stress avoidance or tolerance ${ }^{[35,36]}$. In addition, the likelihood of a single species expressing (1) physiological traits important to stress avoidance when resources are limiting as well as (2) morphological traits important to competitive ability when resources are plentiful is constrained because of the unavoidable tradeoffs between traits that confer stress tolerance and competitive ability ${ }^{[37,38]}$.

Bromus tectorum exhibits traits common among highly competitive species - namely high growth rate, rapid leaf-area development, prolific root production, and rapid capture and depletion of soil resources ${ }^{[27,39,40]}$. In a temporal context, $B$. tectorum also appears to outperform native bunchgrasses in late autumn and early spring during periods of high resource availability ${ }^{[1,42]}$. Similarly, our results confirm that native perennial grasses are unable to match the overall productivity of $B$. tectorum, regardless of watering frequency. However, variation in morphological traits indicate that E. wawawaiensis is more similar to $B$. tectorum compared to the other perennial grasses, especially under frequent watering at $60 \mathrm{~d}$. For example, E. wawawaiensis plants consistently had higher SLA (at both 30 and $60 \mathrm{~d}$ ) and root dry mass at $60 \mathrm{~d}$ than the other perennial grasses under frequent watering. High SLA facilitates rapid early-season growth by maximizing carbon gain per unit leaf mass, and confers competitive and fitness advantages when soil resources are plentiful $^{[43,44]}$. Conversely, low SLA (as shown by E. multisetus and $P$. spicata) is typically correlated with greater leaf longevity and is a common trait for species from nutrientpoor habitats ${ }^{[45,46]}$. Invasive annual grasses with high growth rates also show greater plasticity to soil resources through prolific root production and nutrient acquisition in nutrient-rich microsites than slower-growing perennial grasses $^{[47,48]}$. Viewing the morphological responses of E. wawawaiensis in this ecological context suggests that its plasticity for SLA and root growth is greater than the E. multisetus and P. spicata entries evaluated here. Further research is needed to explore whether these key functionaltrait differences enhance early-season growth and establishment when soil resources are abundant.

In shrub-steppe ecosystems of western North America, where soil resources are temporally available and supplied in seasonal pulses ${ }^{[41,49]}$, it is imperative to determine the processes occurring during pulse- and inter-pulse periods that influence individual plant or population persistence ${ }^{[15]}$. Therefore, when choosing suitable perennial grasses for restoration projects, expression of physiological and morphological traits during these two critical periods is essential. The functional traits expressed by seedings of the grasses in this study indicate that relative to the other grasses, $P$. spicata cv. Goldar is relatively less suited to persist in resource-limited inter-pulse periods. In contrast, the conservative water-use and drought avoidance of E. multisetus selection Sand Hollow may confer greater survival through inevitably stressful inter-pulse periods, especially when soil water has been depleted. The high SLA and root growth of E. wawawaiensis suggests that, of the perennial grasses studied here, it may possess the most rapid growth during pulse periods when invasive annual grasses are most prolific. However, the responses we observed for these particular perennial grasses should not be used to characterize entire species, since we used specific genetic material in our studies. In addition, our studies were conducted under controlled conditions, thus 
they do not take into account potential growth differences under variable and/or cooler temperatures common in field settings where $B$. tectorum is most successful ${ }^{[50,51]}$. Species differences in drought avoidance or competitive ability under lower temperatures that coincide with greater resource availability in shrub-steppe ecosystems are poorly understood ${ }^{[13,49]}$. More research is needed to understand the temperature dependence of key growth processes, including root growth and resource acquisition of perennial grass species used for restoration in shrub-steppe ecosystems.

\section{Conclusions}

Physiological and morphological trait variation not only provide criteria for selecting plant material for restoration projects, but also indicate the necessity for utilizing multiple species to grow and utilize resources during pulse- and inter-pulse periods. Experimental and theoretical studies support the concept that functional diversity of multiple-species plantings or seedings foster more complete nutrient acquisition and improve resistance to weed invasion $^{[52,53]}$. In addition, restoration-seeding efforts indicate that early- and later-establishing mixtures differ greatly in their ability to suppress annual species ${ }^{[54,55]}$. Multiple-species plantings are also hypothesized to provide greater spatial acquisition of resources ${ }^{[56,57]}$. A promising future linkage between screening functional traits and assessing restoration success may include determining whether multiple-species mixtures, that contain a broad range of functional traits, improve temporal and spatial resource-use such that mixtures effectively coexist and resist annual grass invasion.

\section{Implications}

- When choosing plant material for restoration, performance during both pulse (resource-rich) and interpulse (resource-poor) periods should be considered.

- Established plants from plant material that best match performance of critical invasive species are most likely to be able to compete effectively.

- Physiological and morphological traits within a species suggest which plant materials are most likely to be successful competitors of B. tectorum.

- When assembling a seeding mix, aiming for high functional diversity, both among species and among selections within a species, may enhance the resistance for the plant community to weed invasion.

Acknowledgements We graciously thank Justin Williams, Brian Bell, Tonya Shoemaker, Dale Nielson, and Eamonn Leonard for assisting with data collection and seedling maintenance. We also thank Drs J. Leffler and B. Geary for reviewing a previous version of this manuscript.
Compliance with ethics guidelines Huiqin He, Thomas A. Monaco, and Thomas A. Jones declare they have no conflicts of interest or financial conflicts to disclose.

This article does not contain any studies with human or animal subjects performed by any of the authors.

\section{References}

1. Passey H B, Hugie V K. Variation in bluebunch wheatgrass in relation to environment and geographic location. Ecology, 1963, 44 (1): 158-161

2. Daubenmire R F. Plant succession due to overgrazing in the Agropyron bunchgrass prairie of southeastern Washington. Ecology, 1940, 21(1): 55-64

3. West N E. Western intermountain sagebrush steppe. In: West N E. ed. Temperate deserts and semi-deserts. Amersterdam: Elsevier, 1983

4. Pickford G D. The influence of continued heavy grazing and of promiscuous burning on spring-fall ranges in Utah. Ecology, 1932, 13(2): 159-171

5. Hironaka M, Tisdale E W. Secondary succession in annual vegetation in southern Idaho. Ecology, 1963, 44(4): 810-812

6. Rogler G A, Lorenz R. Crested wheatgrass: early history in the United States. Journal of Range Management, 1983, 36(1): 91-93

7. Asay K H, Horton W H, Jensen K B, Palazzo A J. Merits of native and introduced triticeae grasses on semiarid rangelands. Canadian Journal of Plant Science, 2001, 81(1): 45-52

8. Roundy B A. Lessons from historical rangeland revegetation for today's restoration. In: Holzworth L K, Brown R W. eds. Proceedings: 1997 Society for Ecological Restoration annual meeting. RMRS-P-8. Ogden, UT: U.S. Department of Agriculture, Forest Service, Rocky Mountain Research Station, 1999

9. Melgoza G, Nowak R S, Tausch R J. Soil water exploitation after fire: competition between Bromus tectorum (cheatgrass) and two native species. Oecologia, 1990, 83(1): 7-13

10. Monaco T A, Johnson D A, Norton J M, Jones T A, Connors K J, Norton J B, Redinbaugh M B. Contrasting responses of Intermountain West grasses to soil nitrogen. Journal of Range Management, 2003, 56(3): 282-290

11. Leffler A J, Monaco T A, James J J. Nitrogen acquisition by annual and perennial grass seedlings: testing the roles of performance and plasticity to explain plant invasion. Plant Ecology, 2011, 212(10): $1601-1611$

12. Mukherjee J R, Jones T A, Adler P B, Monaco T A. Drought tolerance in two perennial bunchgrasses used for restoration in the Intermountain West, USA. Plant Ecology, 2011, 212(3): 461-470

13. Leffler A J, James J J, Monaco T A. Temperature and functional traits influence differences in nitrogen uptake capacity between native and invasive grasses. Oecologia, 2013, 171(1): 51-60

14. Sheley R L, James J J. Simultaneous intraspecific facilitation and interspecific competition between native and annual grasses. Journal of Arid Environments, 2014, 104(1): 80-87

15. Goldberg D, Novoplansky A. On the relative importance of competition in unproductive environments. Journal of Ecology, 1997, 85(4): 409-418 
16. Kujawski J, Ogle D. Not your grandpa's cultivars: the new conservation releases. Native Plants Journal, 2005, 6(1): 49-51

17. Sack L, Holbrook N M. Leaf hydraulics. Annual Review of Plant Biology, 2006, 57(1): 361-381

18. Boyer J S. Pressure chamber. In: Boyer J S. ed. Measuring the water status of plants and soils. Lewes, Delaware, USA: Academic Press, 1995

19. Fernández R J, Reynolds J F. Potential growth and drought tolerance of eight desert grasses: lack of a trade-off? Oecologia, 2000, 123(1): 90-98

20. Ries R E, Svejcar T J. The grass seedling: when is it established. Journal of Range Management, 1991, 44(6): 574-576

21. Hardegree S P, Van Vactor S S. Microclimatic constraints and revegetation planning in a variable environment. Weed Technology, 2004, 18(S1): 1213-1215

22. Jones T A, Nielson D C, Carlson J R. Developing a grazing-tolerant native grass for bluebunch wheatgrass sites. Rangelands, 1991, 13 (3): $147-150$

23. Pechanec J F. The identification of grasses on the upper Snake River Plains by their vegetative characters. Ecology, 1936, 17(3): 479-490

24. Ehleringer J R, Mooney H A. Leaf hairs: Effects on physiological activity and adaptive value to a desert shrub. Oecologia, 1978, 37 (2): $183-200$

25. Raschke K. Heat transfer between the plant and the environment. Annual Review of Plant Physiology, 1960, 11(1): 111-126

26. Hironaka M, Sindelar B W. Growth characteristics of squirreltail seedliings in competition with medusahead. Journal of Range Management, 1975, 28(4): 283-285

27. Arredondo J T, Jones T A, Johnson D A. Seedling growth of Intermountain perennial and weedy annual grasses. Journal of Range Management, 1998, 51(5): 584-589

28. Clausnitzer D W, Borman M M, Johnson D E. Competition between Elymus elymoides and Taeniatherum caput-medusae. Weed Science, 1999, 47(6): 720-728

29. Jones T A. Viewpoint: the present status and future prospects of squirreltail research. Journal of Range Management, 1998, 51(3): 326-331

30. Kulmatiski A, Beard K H, Stark J M. Exotic plant communities shift water-use timing in a shrub-steppe ecosystem. Plant and Soil, 2006, 288(1-2): 271-284

31. Gibbs J L, Young G, Carlson J R. Registration of 'Goldar' bluebunch wheatgrass. Crop Science, 1991, 31(6): 1708

32. Zhao D L, Atlin G N, Bastiaans L, Spiertz J H J. Developing selection protocols for weed competitiveness in aerobic rice. Field Crops Research, 2006, 97(2-3): 272-285

33. Atwater D Z, James J J, Leger E A. Seedling root traits strongly influence field survival and performance of a common bunchgrass. Basic and Applied Ecology, 2015, 16(2): 128-140

34. Larson J E, Sheley R L, Hardegree S P, Doescher P S, James J J. Do key dimensions of seed and seedling functional trait variation capture variation in recruitment probability? Oecologia, 2016, 181 (1): $39-53$

35. Tilman D. Constraints and tradeoffs: toward a predictive theory of competition and succession. Oikos, 1990, 58(1): 3-15

36. Jannink J L, Jordan N R, Orf J H. Feasibility of selection for high weed suppressive ability in soybean: absence of tradeoffs between rapid initial growth and sustained later growth. Euphytica, 2001, 120(2): 291-300

37. Chapin F S III. The mineral nutrition of wild plants. Annual Review of Ecology and Systematics, 1980, 11(1): 233-260

38. Aerts R, Chapin F S III. The mineral nutrition of wild plants revisited: a re-evaluation of processes and patterns. Advances in Ecological Research, 2000, 30(1): 1-67

39. Svejcar T. Root length, leaf area, and biomass of crested wheatgrass and cheatgrass seedlings. Journal of Range Management, 1990, 43 (5): 446-448

40. Cui M, Caldwell M M. A large ephemeral release of nitrogen upon wetting of dry soil and corresponding root responses in the field. Plant and Soil, 1997, 191(2): 291-299

41. Bilbrough C J, Caldwell M M. Exploitation of springtime ephemeral N pulses by six Great Basin plant species. Ecology, 1997, 78(1): 231-243

42. Booth M S, Caldwell M M, Stark J M. Overlapping resource use in three Great Basin species: implications for community invasibility and vegetation dynamics. Journal of Ecology, 2003, 91(1): 36-48

43. van der Werf A, van Nuenen M, Visser A J, Lambers $H$. Contribution of physiological and morphological plant traits to a species' competitive ability at high and low nitrogen supply: a hypothesis for inherently fast- and slow-growing monocotyledonous species. Oecologia, 1993, 94(3): 434-440

44. Poorter H, Evans J R. Photosynthetic nitrogen-use efficiency of species that differ inherently in specific leaf area. Oecologia, 1998, 116(1-2): 26-37

45. Elberse W T, Berendse F. A comparative study of the growth and morphology of eight grass species from habitats with different nutrient availabilities. Functional Ecology, 1993, 7(2): 223-229

46. Reich P B, Ellsworth D S, Walters M B, Bose J M, Gresham C, Bolim J C, Bowman W D. Generality of leaf trait relationships: a test across six biomes. Ecology, 1999, 80(6): 1955-1969

47. Aanderud Z T, Bledsoe C S, Richards J H. Contribution of relative growth rate to root foraging by annual and perennial grasses from California oak woodlands. Oecologia, 2003, 136(3): 424-430

48. Hodge A. The plastic plant: root responses to heterogeneous supplies of nutrients. New Phytologist, 2003, 162(1): 9-24

49. Blank R R, Chambers J C, Roundy B A, Whittaker A. Nutrient availability in rangeland soils: Influence of prescribed burning, herbaceous vegetation removal, overseeding with Bromus tectorum, season, and elevation. Rangeland Ecology and Management, 2007, 60(6): 644-655

50. Aguirre L, Johnson D A. Influence of temperature and cheatgrass competition on seedling development of two bunchgrasses. Journal of Range Management, 1991, 44(4): 347-354

51. Monaco T A, Monsen S B, Smith B N, Hansen L D. Temperaturedependent physiology of Poa secunda, a cool season grass native to the Great Basin, United States. Russian Journal of Plant Physiology: a Comprehensive Russian Journal on Modern Phytophysiology, 2005, 52(5): 653-658

52. Davis M A, Grime J P, Thompson K. Fluctuating resources in plant communities: a general theory of invasibility. Journal of Ecology, 2000, 88(3): 528-534

53. Davies K W, Pokorny M L, Sheley R L, James J J. Influence of plant functional group removal on inorganic soil nitrogen concentrations 
in native grasslands. Rangeland Ecology and Management, 2007, 60(3): $304-310$

54. Waldron B L, Monaco T A, Jensen K B, Harrison R D, Palazzo A J, Kulbeth J D. Coexistence of native and introduced perennial grasses following simultaneous seeding. Agronomy Journal, 2005, 97(3): 990-996

55. Ralphs M H, Monaco T A, Valdez J R, Graham D. Seeding coolseason grasses to suppress white locoweed (Oxytropis sericea) reestablishment and increase forage production. Weed Technology,
2007, 21(3): 661-669

56. Mangold J M, Poulsen C L, Carpinelli M F. Revegetating Russian knapweed (Acroptilon repens) infestations using morphologically diverse species and seedbed preparation. Rangeland Ecology and Management, 2007, 60(4): 378-385

57. Leffler A J, Leonard E D, James J J, Monaco T A. Invasion is contingent on species assemblage and invasive species identity in experimental rehabilitation plots. Rangeland Ecology and Management, 2014, 67(6): 657-666 